\title{
Exposure from the Chernobyl accident had adverse effects on erythrocytes, leukocytes, and, platelets in children in the Narodichesky region, Ukraine: A 6-year follow-up study
}

\author{
Eugenia Stepanova1, Wilfried Karmaus*2, Marina Naboka ${ }^{3}$, \\ Vitaliy Vdovenko ${ }^{1}$, Tim Mousseau ${ }^{4}$, Viacheslav M Shestopalov ${ }^{3}$, John Vena ${ }^{2}$, \\ Erik Svendsen ${ }^{2}$, Dwight Underhill ${ }^{5}$ and Harris Pastides ${ }^{2}$
}

Address: ${ }^{1}$ Scientific Center for Radiation Medicine, Academy of Medical Sciences of Ukraine, Kyiv, Ukraine, ${ }^{2}$ Department of Epidemiology and Biostatistics, Norman J. Arnold School of Public Health, University of South Carolina, Columbia, South Carolina, USA, ${ }^{3}$ Radioecological Center, Ukrainian National Academy of Sciences, Kyiv, Ukraine, ${ }^{4}$ College of Arts and Sciences, University of South Carolina, Columbia, South Carolina, USA and ${ }^{5}$ Department of Environmental Health Science, Norman J. Arnold School of Public Health, University of South Carolina, Columbia, South Carolina, USA

Email: Eugenia Stepanova - profstepanova@i.ua; Wilfried Karmaus* - karmaus@sc.edu; Marina Naboka - marinavn1@yahoo.com; Vitaliy Vdovenko - xrisk06@yahoo.com; Tim Mousseau - mousseau@sc.edu; Viacheslav M Shestopalov - vsh@hydrosafe.kiev.ua; John Vena - Jvena@gwm.sc.edu; Erik Svendsen - svendsee@gwm.sc.edu; Dwight Underhill - dmunderhill@gmail.com; Harris Pastides - Pastides@gwm.sc.edu

* Corresponding author

Published: 30 May 2008

Environmental Health 2008, 7:21 doi:10.1186/1476-069X-7-21
Received: 23 November 2007

Accepted: 30 May 2008

This article is available from: http://www.ehjournal.net/content/7/I/2I

(C) 2008 Stepanova et al; licensee BioMed Central Ltd.

This is an Open Access article distributed under the terms of the Creative Commons Attribution License (http://creativecommons.org/licenses/by/2.0), which permits unrestricted use, distribution, and reproduction in any medium, provided the original work is properly cited.

\begin{abstract}
Background: After the Chernobyl nuclear accident on April 26, 1986, all children in the contaminated territory of the Narodichesky region, Zhitomir Oblast, Ukraine, were obliged to participate in a yearly medical examination. We present the results from these examinations for the years 1993 to 1998. Since the hematopoietic system is an important target, we investigated the association between residential soil density of ${ }^{137}$ Caesium $\left({ }^{137} \mathrm{Cs}\right)$ and hemoglobin concentration, and erythrocyte, platelet, and leukocyte counts in I,25I children, using 4,989 repeated measurements taken from 1993 to 1998.

Methods: Soil contamination measurements from 38 settlements were used as exposures. Blood counts were conducted using the same auto-analyzer in all investigations for all years. We used linear mixed models to compensate for the repeated measurements of each child over the six year period. We estimated the adjusted means for all markers, controlling for potential confounders.

Results: Data show a statistically significant reduction in red and white blood cell counts, platelet counts and hemoglobin with increasing residential ${ }^{137} \mathrm{Cs}$ soil contamination. Over the six-year observation period, hematologic markers did improve. In children with the higher exposure who were born before the accident, this improvement was more pronounced for platelet counts, and less for red blood cells and hemoglobin. There was no exposurextime interaction for white blood cell counts and not in 702 children who were born after the accident. The initial exposure gradient persisted in this sub-sample of children.

Conclusion: The study is the first longitudinal analysis from a large cohort of children after the Chernobyl accident. The findings suggest persistent adverse hematological effects associated with residential ${ }^{137} \mathrm{Cs}$ exposure.
\end{abstract}




\section{Background}

An explosion at the Chernobyl nuclear power plant on April 26, 1986, the worst accident in the history of nuclear power, resulted in radioactive pollution of much of the surrounding area. In the Ukraine, 2,293 villages and towns with a population of 2.6 million inhabitants were contaminated. A plume of radioactive fallout drifted over parts of Europe and reaching eastern North America, as well. Ever since, the public in these areas has been exposed to radiation, both externally and internally via contaminated locally-grown food, water and air.

Estimates of detrimental health effects from chronic radiation exposure vary widely [1]. Nearly 20 years after the Chernobyl disaster the World Health Organization in a report of the UN Chernobyl Forum found no evidence for an increased incidence of leukemia [2]. However, the same report found a complete lack of analytical studies in which dose and risks were estimated on an individual level. There were a few studies that analyzed white blood cells but most were based on a small number of children, focused mainly on micronuclei, and were often inconclusive [3-8]. Lenskaia et al., analyzed blood smears from 820 children living in a the Bryansk area in Russia and 46 controls from non-contaminated areas [9]. Using cytochemical assays (mucopolysaccharids) and esterase in 464 children with various exposure levels and 46 children from non-contaminated areas the work showed a reduction of mature T-lymphocytes and an increase of immature B-lymphocytes. In 1994-1996, Vykhovanets et al. and Chernyshov et al. studied T-lymphocytes in healthy children, 219 and 120, respectively, and children suffering from recurrent respiratory diseases (RRD) who resided around Chernobyl. Both studies compared the exposed groups with 148 non-exposed children, who were healthy or suffered from RRD. No information of leukocyte counts was provided $[10,11]$.

Regarding red blood cells, we identified six published studies [5,12-16]. Stepanova et al. found more transitory, prehemolytic and degenerative forms of erythrocytes (red blood cells) in exposed children in comparison with control children [14]. Cross-sectional results on blood indices for years 1986, 1992 and 1998 were provided by Bebeshko et al. [16]. The authors examined children in the following age-groups: up to 3,4-7 and 8-15 years old, residing in the Kiev, Zhytomyr, and Chernohiv provinces with ${ }^{137} \mathrm{Cs}$ soil contamination density of $37 \mathrm{kBq} / \mathrm{m}^{2}$ or less (37 kilo Bequerel $/ \mathrm{m}^{2}=1$ Curie $(\mathrm{Ci}) / \mathrm{km}^{2}$ ) and contamination densities between 38 and $55 \mathrm{kBq} / \mathrm{m}^{2}$. The erythrocyte and leukocyte counts were significantly decreased in children aged 0-3 years living in Zhytomyr and in children age 8-15 years living in Chernihiv. The authors found no differences in hemoglobin, erythrocyte, leukocyte and platelet count in children residing in settle- ments with ${ }^{137} \mathrm{Cs}$ soil contamination density of $38-555$ $\mathrm{kBq} / \mathrm{m}^{2}$ compared to $37 \mathrm{kBq} / \mathrm{m}^{2}$.

The Chernobyl Sasakawa Health and Medical Cooperation project conducted the largest cross-sectional investigation of health effects in children [17]. Among a variety of markers, hematological outcomes were determined in 118,773 children residing in more than 80 regions with different radiation exposures from 1991 to 1996, including 779 children from the Narodichi region $[18,19]$. Each region represented a distinct exposed population rather than a regional sample of the larger exposed population. Children from each region were examined at a different points in time and there was no follow-up of each regional cohort in subsequent years. Some children were re-examined, but only those who presented a critical clinical outcome. The Chernobyl Sasakawa Health and Medical Cooperation project was a successful and comprehensive screening project. However, the project was not sufficiently designed to assess differences in health effects in regions and over time. For instance, the result of the exams in different regions and times, though presented as time trends, were confounded by different regions examined in different years [19]. In addition, improvements detected in the re-examinations of children were judged as recovery. This ignores the fact that exclusive examination of observations above a critical value will by chance produce 'recovery' due to chance movements of observations below the cut-off point in the reexam (regression to the mean). Although the results of this study have never been reported in peer-reviewed scientific journals, the project has been influential when assessing the risk of the accident.

No study has yet investigated hematological follow-up data in children exposed from the Chernobyl accident. This motivated us to asses the association between residential soil density of ${ }^{137}$ Caesium $\left({ }^{137} \mathrm{Cs}\right)$ and hemoglobin concentration, and erythrocyte, platelet, and leukocyte counts in repeated measurements taken from 1993 to 1998.

\section{Methods \\ Population}

The settlements in the Narodichesky region (Zhitomir Oblast, Ukraine) are approximately $80 \mathrm{~km}$ from the Chernobyl nuclear site (Figure 1). Approximately 11,400 people reside in this region, including about 2,000 children [20]. Three quarters of its population live in rural villages, the others in small towns. The food supply is predominantly locally grown. To monitor the health effects of the accident, since 1986 every child from birth to age 18 in the contaminated territory was required to have a yearly medical examination. The Human Subject Committee at the University of South Carolina has approved these analyses. 


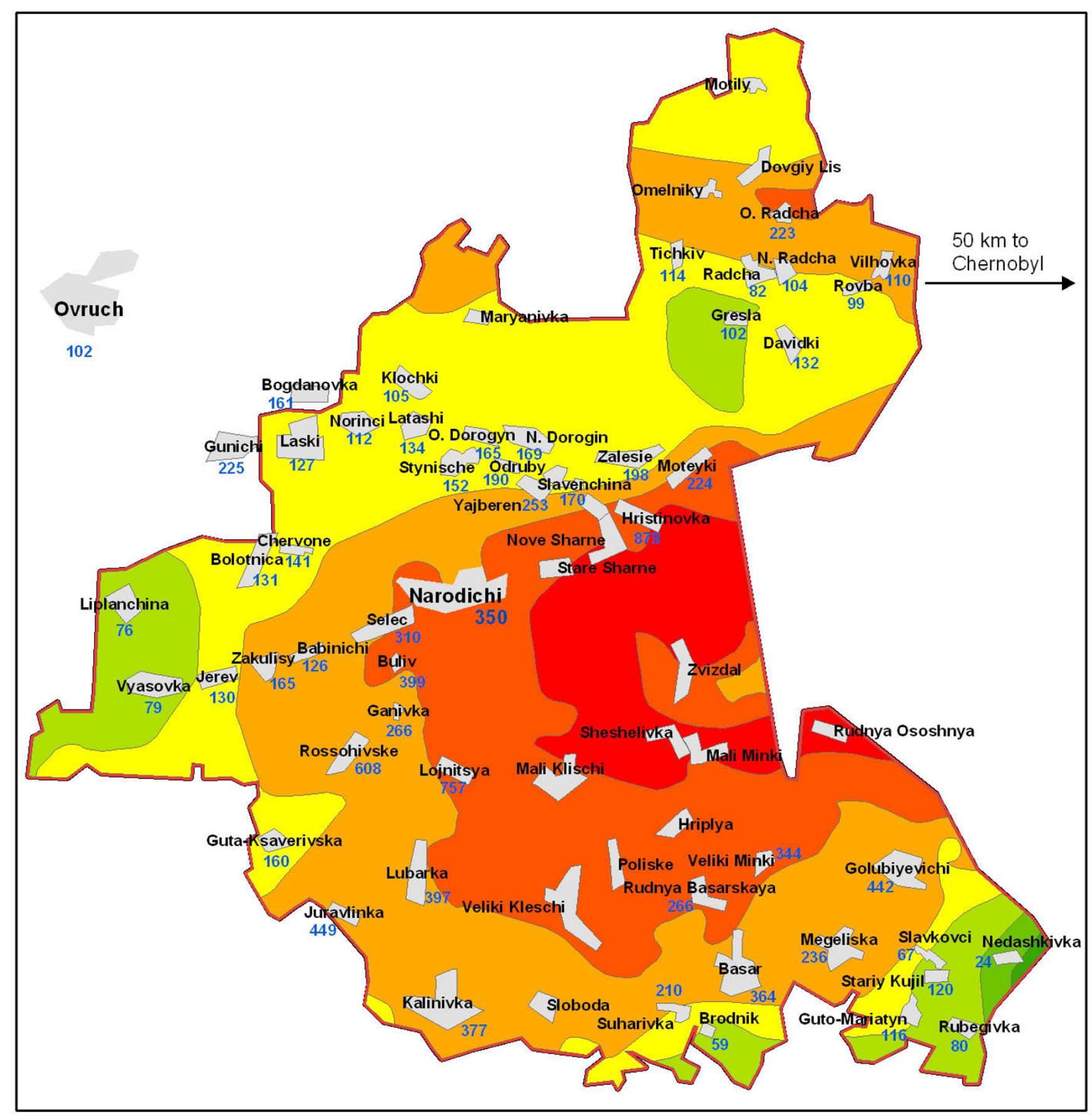

Figure I

Map of the Narodychi region's territory soil pollution by ${ }^{137} \mathrm{Cs}$.

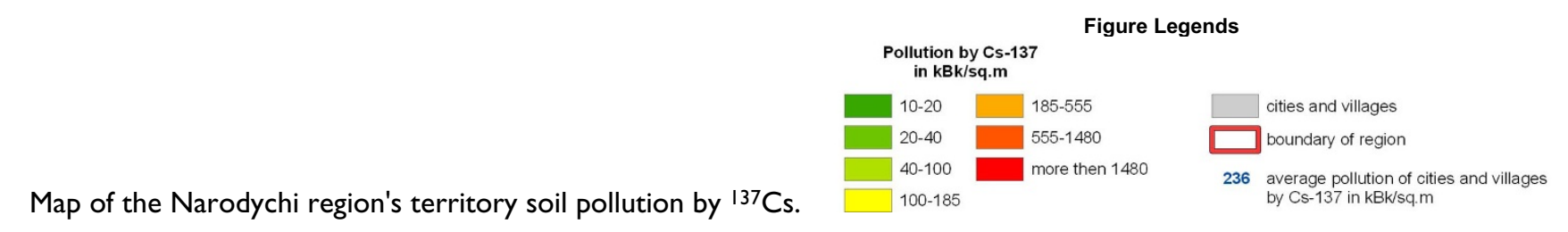

Figure Legends 


\section{Exposure measurement}

Following the Chernobyl accident, soil became contaminated with ${ }^{137} \mathrm{Cs}$, a nuclear fission product that has a halflife of 30 years, and emits both beta- and gamma-irradiation (Figure 1). The highest levels of ${ }^{137} \mathrm{Cs}$ were found in the surface layers of the soil where it is absorbed by plants and mushrooms, thereby entering the local food supply. Dosimetric assessments of settlements in the Ukraine contaminated by radionuclides were published from 1991 to 2005 in 10 reports [21]. In addition, the Ministry of Emergency Situations provided spatial data on radiation [22]. Soil measurements used in this work represent the average of numerous measurements in each village over several years, in particular 1991-1993. These averages were officially named 'certifications' and documented in publications by the Ministry of Health. [21]. Since residential and individual ${ }^{137} \mathrm{Cs}$ levels are highly correlated, we used the contamination in the residential area as an approximation of individual exposure [23].

\section{Medical examination}

The obligatory medical examination included weight and height measurements, blood sampling, blood pressure, ultrasound measurements (thyroid, abdomen and kidney and adrenals), lung function (starting with a height of 100 $\mathrm{cm}$ ), and a medical history. Gender and place of residence were also noted. No other information on living conditions or tobacco smoke exposure was collected as a part of this exam. For these obligatory examinations, no parental consent was required.

This work is a first in a series of longitudinal analyses. Here we focus on hematologic function: erythrocytes (red blood cells), leukocytes (white blood cells), and thrombocyte (platelet) count and hemoglobin concentrations. Blood was collected in tubes containing EDTA. A blood count, including erythrocytes, hemoglobin, leukocytes, and thrombocytes, was conducted using Sysmex model F800 (TOA Medical Electronics Company, Kobe, Japan). Normal blood smears were stained by the standardized azure B-eosin GIEMSA Y Romanowsky procedure. Results of these investigations were entered into a database for the period of 1993 to1998.

\section{Statistical Analysis}

For descriptive purposes, values beyond clinical reference levels were defined in Table 1[24].

Data were analyzed using the statistical package SAS Version 9.1 (SAS Institute Inc., Cary, NC, USA). We had six repeated measurements of red and white blood cell markers. To determine whether the measurements agreed over time, we estimated intraclass correlation coefficients for the repeated measurements [25].

To investigate the effect of residential ${ }^{137} \mathrm{Cs}$ radiation, we used linear models for repeated measurements (PROC MIXED) [26]. This statistical method compensates for the repeated measurements of each child over the six crosssectional models (1993-1998). For all markers, we estimated the adjusted means, controlling for confounders.

For the statistical estimation, the regular maximum likelihood method was applied. This model requires that the random effects and the error vector are normally distributed, which was found to be the case for all markers. For the within-subject association, modeling started with an unstructured covariance model which required least constraints. For the repeated measurements, the initial model used serial correlation structures (Gaussian). Based on the Akaike information criterion (AIC), we could simplify the random effect to variance component, but could not simplify the repeated measurement matrix.

The residential measurements of ${ }^{137} \mathrm{Cs}$ were ranked into five groups of nearly equal size (PROC RANK), with each rank treated as an indicator variable, facilitating assessing an exposure-response relationship. As for confounding factors, the statistical models included gender, age, and year of measurement. Age was categorized into 18 indicator variables of one-year intervals, with the first group 01.5 years old. We used indicator variables for age and year

Table I: Values beyond clinical reference levels.

\begin{tabular}{lll}
\hline Red blood cell count: & younger than 2 years: & $\geq 3.7 \times 10^{12} \mathrm{cells} / \mathrm{L}$ \\
& 2 years and younger than 6: & $\geq 3.9 \times 10^{12} \mathrm{cells} / \mathrm{L}$ \\
& 6 years and younger than $12:$ & $\geq 4.0 \times 10^{12} \mathrm{cells} / \mathrm{L}$ \\
& 12 years and younger than $18:$ & $\geq 4.5 \times 10^{12} \mathrm{cells} / \mathrm{L}$ \\
Hemoglobin: & younger than 6 years: & $\geq 5.59 \mathrm{mmol} / \mathrm{L}(9 \mathrm{~g} / \mathrm{dL})$ \\
& 6 years and younger than $12:$ & $\geq 7.14 \mathrm{mmol} / \mathrm{L}(\mathrm{II} .5 \mathrm{~g} / \mathrm{dL}$ \\
& 12 years and older: & $\geq 7.76 \mathrm{mmol} / \mathrm{L}(12.5 \mathrm{~g} / \mathrm{dL})$ \\
Thrombocytes: & all ages: & $\geq 150 \times 10^{9} \mathrm{platelets} / \mathrm{L}$ \\
Leukocytes: & 1 to 3 years: & $\geq 6-17.5 \times 10^{9} \mathrm{cells} / \mathrm{L}$ \\
& 4 to 7 years: & $\geq 5.5-15.5 \times 10^{9} \mathrm{cells} / \mathrm{L}$ \\
& 8 to 13 years: & $\geq 4.5-13.5 \times 10^{9} \mathrm{celll} / \mathrm{L}$ \\
& 13 years and older: & $\geq 4.5-11.0 \times 10^{9} \mathrm{cells} / \mathrm{L}$
\end{tabular}


Table 2: Villages, soil contamination, number of participating children and measurements $\psi$

\begin{tabular}{|c|c|c|c|c|c|c|}
\hline \multirow[t]{2}{*}{ Village } & \multirow[t]{2}{*}{ Quintile } & \multirow[t]{2}{*}{ Soil contamination ${ }^{137}$ Caesium $\left(\mathrm{kBq} / \mathrm{m}^{2}\right)$} & \multicolumn{2}{|c|}{ Children } & \multicolumn{2}{|c|}{ Repeated measurements } \\
\hline & & & Number & $\%(n=1247)$ & Number & $\%(n=4,981)$ \\
\hline Brodnik & & 59 & 11 & 0.9 & 37 & 0.7 \\
\hline Slavkovci & & 67 & 9 & 0.7 & 36 & 0.7 \\
\hline Liplanchina & & 76 & & & & \\
\hline Vyasovka & & 79 & 60 & 4.8 & 262 & 5.3 \\
\hline Rubegivka & 0 & 80 & 50 & 4.0 & 205 & 4.1 \\
\hline Radcha & & 82 & & & & \\
\hline Ovruch & & 102 & 4 & 0.3 & 14 & 0.3 \\
\hline N. Radcha & & 104 & & & & \\
\hline Klochki & & 105 & 25 & 2.0 & 79 & 1.6 \\
\hline Gresla & & 102 & 5 & 0.4 & 29 & 0.6 \\
\hline Norinci & & 112 & 71 & 5.7 & 305 & 6.1 \\
\hline Guto-Mariatyn & & 116 & 24 & 1.9 & 97 & 1.9 \\
\hline Babinichi & & 126 & 9 & 0.7 & 45 & 0.9 \\
\hline Laski & & 127 & 75 & 6.0 & 317 & 6.4 \\
\hline Jerev & I & 130 & 28 & 2.2 & 111 & 2.2 \\
\hline Bolotnica & & $13 \mid$ & 53 & 4.3 & 182 & 3.7 \\
\hline Davidki & & 132 & 8 & 0.6 & 38 & 0.8 \\
\hline Latashi & & 134 & 46 & 3.7 & 214 & 4.3 \\
\hline Snytiche & & 152 & 9 & 0.7 & 39 & 0.8 \\
\hline Bogdanovka & & 161 & & & & \\
\hline O. Dorogyn & & 165 & 51 & 4.1 & 220 & 4.4 \\
\hline Zakusily & & 165 & 35 & 2.8 & 120 & 2.4 \\
\hline N. Dorogin & & 169 & 22 & 1.8 & 71 & 1.4 \\
\hline Slavichina & & 170 & 7 & 0.6 & 30 & 0.6 \\
\hline Odruby & 2 & 190 & 6 & 0.5 & 11 & 0.2 \\
\hline Zalesie & & 198 & 55 & 4.4 & 217 & 4.4 \\
\hline Suharevka & & 210 & 20 & 1.6 & 64 & 1.3 \\
\hline
\end{tabular}


Table 2: Villages, soil contamination, number of participating children and measurements $\psi$ (Continued)

\begin{tabular}{|c|c|c|c|c|c|c|}
\hline Moteyki & & 224 & 29 & 2.3 & 132 & 2.7 \\
\hline Gunichu & & 225 & 12 & 1.0 & 32 & 0.6 \\
\hline Megeliska & & 236 & & & & \\
\hline Yajberen & & 253 & 19 & 1.5 & 90 & 1.8 \\
\hline Rudnya Basarskaya & 3 & 266 & 116 & 9.3 & 486 & 9.8 \\
\hline Selec & & 310 & & & & \\
\hline Narodichi & & 350 & 279 & 22.4 & 1,049 & 21.1 \\
\hline Basar & 4 & 364 & 103 & 8.3 & 433 & 8.7 \\
\hline Rossohivske & & 608 & 6 & 0.5 & 16 & 0.3 \\
\hline Hristinovka & & 879 & & & & \\
\hline
\end{tabular}

$\psi$ Villages with a small number of children/observations were merged for descriptive purposes.

of observation to investigate whether their relationships with the outcome variables were linear. If not, these indicator variables adjusted for non-linearity - for instance as we did with erythrocyte counts and age in girls. To determine whether the change in the distribution of the blood markers over the time of the observation depends also on the residential radiation level, we included an interaction term of time (year of measurement) and ${ }^{137} \mathrm{Cs}$. In addition, we investigated statistical differences in children born before or after the accident.

\section{Results}

Children from 38 different settlements were included in the cohort (Table 2). All villages had different soil measurements of ${ }^{137} \mathrm{Cs}$ (Figure 1), ranging from 29 to $879 \mathrm{kBq} /$ $\mathrm{m}^{2}$ (Figure 1). The average measurements shown for each settlement within colored zones are based on contamination modeling. Average values and the colored zones were retrieved from published data $[21,22]$. Three villages were at the border or outside of the Narodichesky region (Bogdanovka, Gunichu, and Ovruch, total of 3 children). Due to the distribution of ${ }^{137} \mathrm{Cs}$, quintiles of the exposure did not produce equally sized groups (Table 3 ).

The exact number of children residing in the Narodichesky region between 1993 to 1998 is unknown. Of the 11,400 residents, approximately 2,000 children are children. Data of all exams (1993 to 1998) were included. Officially, participation in the exams was obligatory. However, authorities did not enforce participation. Hence, the term 'obligatory' primarily reflects the opportunity of having annual examinations. Overall, approximately $75 \%$ participated in at least one of the examinations $(1,459$ of about 2,000 children residing in the region). Of these, 1,247 children had a blood sample analyzed (86\%), which resulted in 4,981 repeated measurements (Table 3 ). About one third of the children were 4.5 years and younger, but only $15.9 \%$ of the measurements came from these children, indicating a lower participation in blood sampling. The oldest child was born in 1979; the youngest in 1996. Data from the children born in 1986 will be analyzed and reported in a separate paper. Of our cohort, 549 children were born before and 698 after the accident (Table 3 ). In $75 \%$ of the available data, the first participation was documented in 1993, however, the measurements were nearly equally distributed throughout the years. In 1993, we had 886 measurements; 786 in 1994; 787 in 1995; 783 in 1996; 1,030 in 1997; and 709 in 1998.

Because erythrocyte count and hemoglobin concentration measurement represent a nearly identical feature, these markers are highly correlated $(r=0.72$, Table 4$)$. The other markers did not show high rank-correlations indicating independent measurements.

The intraclass-correlation coefficients (ICC) for the four markers over the six years are: erythrocyte count: $\mathrm{ICC}=0.4$ ( $5 \%$ confidence level: 0.37 ), for hemoglobin: ICC $=0.59$ (5\% confidence level: 0.57 ), for thrombocyte count: ICC $=0.54(5 \%$ confidence level: 0.52$)$, and for leukocyte count: ICC $=$ ICC $=0.53$ ( $5 \%$ confidence level: 0.51 ). These results document substantial stability of the measurements. 
Table 3: Characteristics of the study population

\begin{tabular}{|c|c|c|}
\hline & Children participating $(n=1,247) \%$ & Total number of observations $(n=4,981) \%$ \\
\hline \multicolumn{3}{|l|}{ Sex } \\
\hline boys & 49.1 & 48.4 \\
\hline \multicolumn{3}{|c|}{ Age groups (years) (first participation or year) } \\
\hline up to 4.5 & 33.0 & 15.9 \\
\hline$>4.5$ to 9.5 & 37.5 & 33.7 \\
\hline$>9.5$ to 14.5 & 27.4 & 41.1 \\
\hline$>14.5$ & 2.2 & 9.2 \\
\hline \multicolumn{3}{|l|}{ Year of birth } \\
\hline 1979 & 0.2 & 0.1 \\
\hline 1980 & 4.6 & 4.2 \\
\hline$|98|$ & 4.8 & 5.3 \\
\hline 1982 & 8.3 & 9.7 \\
\hline 1983 & 9.7 & 11.4 \\
\hline 1984 & 9.3 & 12.0 \\
\hline 1985 & 7.1 & 9.1 \\
\hline \multicolumn{3}{|l|}{ \# } \\
\hline 1987 & 6.7 & 8.1 \\
\hline 1988 & 8.3 & 9.0 \\
\hline 1989 & 8.5 & 7.7 \\
\hline 1990 & 6.8 & 6.2 \\
\hline 1991 & 6.3 & 5.3 \\
\hline 1992 & 5.9 & 5.1 \\
\hline 1993 & 5.0 & 3.3 \\
\hline 1994 & 5.1 & 2.3 \\
\hline 1995 & 2.7 & 1.0 \\
\hline 1996 & 0.8 & 0.3 \\
\hline \multicolumn{3}{|c|}{ Year of first participation (or first entered into the data) } \\
\hline 1993 & 71.1 & 17.7 \\
\hline 1994 & 2.4 & 15.8 \\
\hline 1995 & 2.7 & 15.8 \\
\hline 1996 & 1.6 & 15.7 \\
\hline 1997 & 18.9 & 20.7 \\
\hline 1998 & 3.4 & 14.3 \\
\hline \multicolumn{3}{|c|}{ Quintiles of the area contamination: ${ }^{137}$ Caesium $\left(\mathrm{kBq} / \mathrm{m}^{2}\right)$} \\
\hline $29-112$ & 18.9 & 19.4 \\
\hline $116-156$ & 20.1 & 20.8 \\
\hline $165-253$ & 9.3 & 19.4 \\
\hline $266-310$ & 31.1 & 9.8 \\
\hline $350-879$ & 18.9 & 30.7 \\
\hline
\end{tabular}

\# Children born in 1986 being analyzed and reported in a separate paper

Table 4: Median, minimal and maximal values, and rank correlation of hematological markers \#

\begin{tabular}{|c|c|c|c|c|c|c|}
\hline \multirow[t]{2}{*}{ Variable } & \multirow[t]{2}{*}{ Median } & \multirow[t]{2}{*}{ Min } & \multirow[t]{2}{*}{ Max } & \multicolumn{3}{|c|}{ Rank correlation (Spearman) and p-value } \\
\hline & & & & Hemoglobin & Leukocyte & Platelets \\
\hline \multirow{2}{*}{ Erythrocyte count (10'2L) } & 4 & 2.1 & 5.7 & 0.72 & 0.25 & 0.22 \\
\hline & & & & 0.00 & 0.00 & 0.00 \\
\hline \multirow[t]{2}{*}{ Hemoglobin $(\mathrm{g} / \mathrm{dL})^{\Phi}$} & 12.3 & 5.2 & 16.9 & & 0.18 & 0.16 \\
\hline & & & & & 0.00 & 0.00 \\
\hline \multirow[t]{2}{*}{ Leukocyte count (106L) } & 6.8 & 2 & 18.9 & & & 0.35 \\
\hline & & & & & & 0.00 \\
\hline Platelet count (1092) & 252 & 108 & 670 & & & \\
\hline
\end{tabular}

\# 4,98I repeated measurement of I,247 children

$\Phi \mid \mathrm{g} / \mathrm{dL}$ equals about $0.6206 \mathrm{mmol} / \mathrm{L}$. 
Including all cohort children, the repeated measurement analyses (mixed models) showed significant effects for the residential ${ }^{137} \mathrm{Cs}$ measurements (quintiles), the time of the medical examination, and the ${ }^{137} \mathrm{Cs} \times$ time interaction (Table 5). To illustrate the interactions of time and exposure, we extracted mean values for residential exposure classes and years from the mixed models (see details in Additional file 1).

The erythrocyte count shows a minor increase from 1993 to 1998 (Figure 2), starting from below $4 \times 10^{12}$ cells per liter to more than $4.1 \times 10^{12}$ cells per liter. The improvement is less in the two groups of children with higher residential exposures; thus the exposure gradient becomes stronger in 1998 compared to 1993. A similar trend is obvious for hemoglobin. Both markers show a dip in 1996, which is not explained by age in general nor by a particular age in girls (age at menarche). For platelet counts, it is obvious that children in all ${ }^{137} \mathrm{Cs}$ exposure groups improved over time (Figure 3 ). The exposure gradient is stronger in 1993, but diminished in 1998. There seems to be no further increase after 1997. Figures 2 and 3 show lower values in 1996 in all exposure groups.

There appears to be exposure-response patterns in all graphs; however, the second to the highest exposure group showed the strongest effect in all four outcomes.
Compared to the second highest group, the highest residential exposure group includes a higher proportion of semi-rural children, from Narodichi, the administrative center of the region (Table 2).

For leukocyte counts, the exposure gradient did not change between 1993 and 1998 (Table 6). Starting with a soil contamination of about $165 \mathrm{kBq} / \mathrm{m}^{2}$, the leukocyte count is approximately 1 million cells per liter lower in the group of children with the highest soil contamination. A similar reduction was found for children born after the accident in 1986 (data not shown). However, the count increased over the time period from 1993 to 1996.

Children born after the accident and thus exposed during pregnancy and childhood showed no ${ }^{137} \mathrm{Cs} \times$ time interaction (Table 7). For the three outcomes, erythrocyte and platelet count and hemoglobin concentration, the values are significantly lower in the two highest residential exposure groups; the effect is strongest for platelets and white blood cells. Compared with the measurements in 1998 there is an overall improvement over the six years of observation for erythrocyte, platelet, but no clear trend regarding hemoglobin (data not shown).

Fifty-three percent of all erythrocyte counts were below the clinical age-specific reference values, as were $19 \%$ of

Table 5: Statistics of the models including the interaction of area contamination and year of measurement \#

\begin{tabular}{|c|c|c|c|c|}
\hline & Numerator degree of freedom & Denominator degree of freedom & $\begin{array}{c}\text { F- } \\
\text { Value }\end{array}$ & Prob $\mathrm{F}$ \\
\hline \multicolumn{5}{|l|}{ Erythrocyte count } \\
\hline $\begin{array}{l}\text { Quintiles of the area contamination with Caesium } 137 \\
\left(\mathrm{kBq} / \mathrm{m}^{2}\right)\end{array}$ & 4 & 3692 & 12.55 & $\begin{array}{c}<0.00 \\
1\end{array}$ \\
\hline Sex & 1 & 3692 & 12.11 & $\begin{array}{c}<0.00 \\
1\end{array}$ \\
\hline Age groups & 17 & 3692 & 13.42 & $\begin{array}{c}<0.00 \\
1\end{array}$ \\
\hline Year of measurement & 5 & 3692 & 102.42 & $\begin{array}{c}<0.00 \\
1\end{array}$ \\
\hline $\begin{array}{l}\text { Quintiles of the area contamination: }{ }^{137} \text { Caesium }\left(\mathrm{kBq} / \mathrm{m}^{2}\right) \times \\
\text { year }\end{array}$ & 20 & 3692 & 5.37 & $\begin{array}{l}<0.00 \\
1\end{array}$ \\
\hline \multicolumn{5}{|l|}{ Hemoglobin } \\
\hline $\begin{array}{l}\text { Quintiles of the area contamination with Caesium } 137 \\
\left(\mathrm{kBq} / \mathrm{m}^{2}\right)\end{array}$ & 4 & 3692 & 7.28 & $\begin{array}{c}<0.00 \\
1\end{array}$ \\
\hline Sex & 1 & 3692 & 7.72 & 0.006 \\
\hline Age groups & 17 & 3692 & 33.43 & $\begin{array}{c}<0.00 \\
1\end{array}$ \\
\hline Year of measurement & 5 & 3692 & 52.68 & $\begin{array}{c}<0.00 \\
1\end{array}$ \\
\hline $\begin{array}{l}\text { Quintiles of the area contamination: }{ }^{137} \text { Caesium }\left(\mathrm{kBq} / \mathrm{m}^{2}\right) \times \\
\text { year }\end{array}$ & 20 & 3692 & 4.81 & $\begin{array}{c}<0.00 \\
1\end{array}$ \\
\hline \multicolumn{5}{|l|}{ Platelet count } \\
\hline $\begin{array}{l}\text { Quintiles of the area contamination with Caesium } 137 \\
\left(\mathrm{kBq} / \mathrm{m}^{2}\right)\end{array}$ & 4 & 3690 & 9.71 & $\begin{array}{c}<0.00 \\
1\end{array}$ \\
\hline Sex & I & 3690 & 1.61 & 0.20 \\
\hline
\end{tabular}




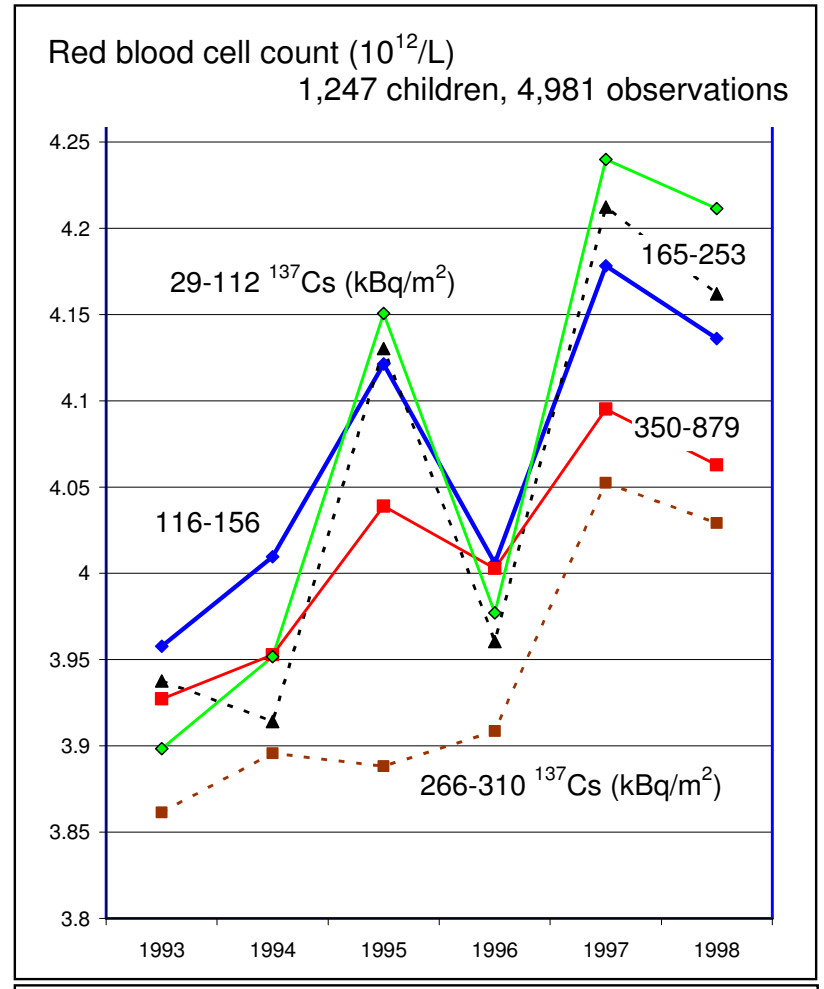

Hemoglobin ( $\mathrm{g} / \mathrm{dL})$
1,247 children, 4,981 observations

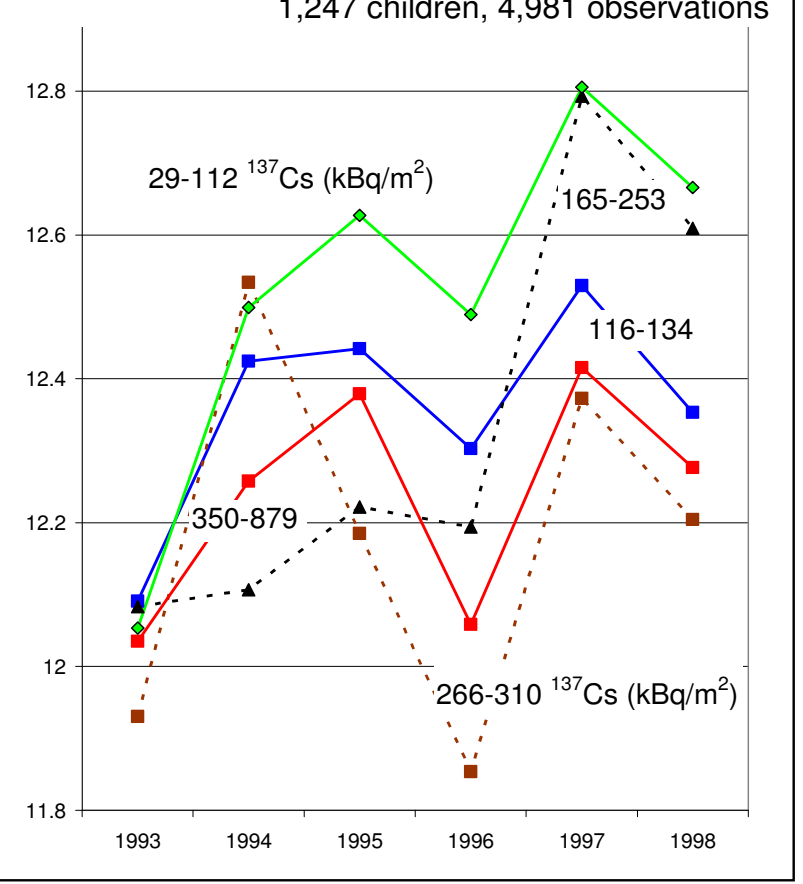

Figure 2

Changes of erythrocyte counts and hemoglobin over the years of observations by ${ }^{137} \mathrm{Cs}$ exposure. The ${ }^{137} \mathrm{Cs}$ contamination is grouped into quintiles. For hemoglobin: I g/ $\mathrm{dL}$ equals about $0.6206 \mathrm{mmol} / \mathrm{L}$.

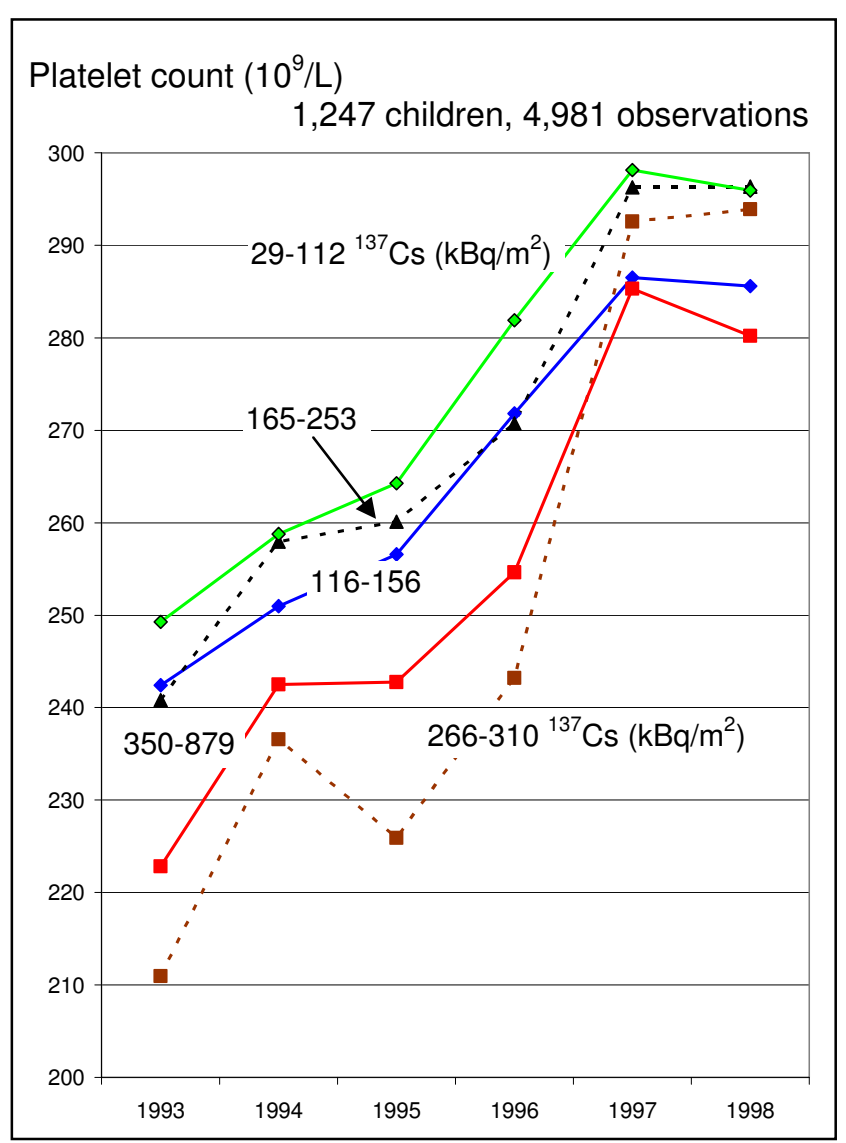

Figure 3

Changes of platelet counts over the years of observations by ${ }^{137} \mathrm{Cs}$ exposure. The ${ }^{137} \mathrm{Cs}$ contamination is grouped into quintiles.

the hemoglobin measurements, $0.7 \%$ of the platelet and $26.6 \%$ of the white blood cell counts. The proportion of values below the clinical limit decreased from 1993 to 1996. The white blood cell counts also showed improvement, but an increasing proportion of mild leukocytosis (white blood cell count > $11 \times 10^{9}$ cells per L; 1993: 0.1\%, 1997: 3.2\%, 1998: 2.0\%).

\section{Discussion}

We analyzed markers of hematopoiesis from 1993 to 1998 and their association with residential radiation exposure and found an adverse effect on erythrocyte, platelet, and white blood cell counts and on hemoglobin concentration. When analyzing the total sample of children irrespective of whether the child was born before or after the accident (exposure occurred in childhood vs. in utero and in childhood), we found that the recovery of platelets was more pronounced in children who were exposed to higher residential contamination with ${ }^{137} \mathrm{Cs}$. The recovery of erythrocytes and hemoglobin was smaller in the highly exposed children. White blood cell counts 
Table 5: Statistics of the models including the interaction of area contamination and year of measurement \# (Continued)

\begin{tabular}{|c|c|c|c|c|}
\hline Age groups & 17 & 3690 & 5.58 & $\begin{array}{c}<0.00 \\
1\end{array}$ \\
\hline Year of measurement & 5 & 3690 & 92.61 & $\begin{array}{c}<0.00 \\
1\end{array}$ \\
\hline $\begin{array}{l}\text { Quintiles of the area contamination: }{ }^{137} \text { Caesium }\left(\mathrm{kBq} / \mathrm{m}^{2}\right) \times \\
\text { year }\end{array}$ & 20 & 3690 & 2.08 & 0.003 \\
\hline
\end{tabular}

\# For the illustration of the results see Figure 2 and 3.

did not show an exposure $\times$ time interaction, but remained lower in higher exposed children. Also in children born after the accident there was no such interaction effect. An outcome improvement was obvious in all exposure groups, with the exception of hemoglobin, but the exposure gradient did not diminish over the observation period.

Overall, approximately $75 \%$ participated in the examinations $(1,459$ of about 2,000 children residing in the region); blood samples were available for $63 \%$. Officially, participation in the exams was obligatory. However, authorities did not enforce participation.

This is a dynamic cohort study: children were entering and leaving the study. Regarding non-participation in one exam, lower or higher levels of the three blood count variables in the preceding exam were not associated with missing the next exam. Hence, we have no indication for a selection bias due to differential attrition.

The justification to enter and analyze only data for 1993 to 1998 was due to budgetary limitations. We are seeking funding to extend the data entry and include more repeated measurements. The 1993 to 1998 period was chosen since all exams were established during this timeframe. Another advantage of this period is that it includes a comparable number of children who were born before the accident in 1986 and thereafter. This facilitates a comparison of exposures occurring after birth in children born before the accident in 1986 with exposure in children born after the accident (persistent 137Cs exposure). The variable "born before" addresses two aspects, first, whether the child was exposed to other short-lived radionuclides immediately after the accident (for instance ${ }^{131}$ Iodine, in children born before 1986), and, second, whether the child was exposed to ${ }^{137} \mathrm{Cs}$ during pregnancy and in its development (born after).

Originally, we planned to analyze radiation exposure using individual effective equivalent dose in millisievert $(\mathrm{mSv})$, which incorporates total external and internal doses, including direct measurements with whole body counts [27], but there are uncertainties in the time periods in which the measurements were taken and their documentation. In addition, the individual effective equivalent dose was not calculated for every child and exposure models for individual dosimetry were changed over time. Although residential radiation exposure introduces more non-differential misclassification and thus weakens possible associations, those data were our most complete available exposure data set. In addition, the Chernobyl Sasakawa Health and Medical Cooperation project found that individual ${ }^{137} \mathrm{Cs}$ levels in the bodies of children were highly correlated $(\mathrm{r}=0.7, \mathrm{p}<0.01)$ with the contamination level in the place of residence [23]. However, compared to the five groups of residential exposure, the individual effective equivalent dose is highest in children in the second to highest residential exposure group (mean individual effective equivalent doses over increasing levels of residential exposure groups: 13.6, 11.7, 16.7, 34.9, 19.6 $\mathrm{mSv})$. Thus, it is likely that the stronger effect in the second highest residential exposure $\left(266-310{ }^{137} \mathrm{Cs} \mathrm{kBq} / \mathrm{m}^{2}\right)$ follows from the higher individual dose in this group. We note that the highest exposure group represents children from Narodichi, the largest village of the region (Table 2),

Table 6: Estimate effects of ${ }^{137}$ Caesium and year of measurements on white blood cell counts $\Psi$

\begin{tabular}{|c|c|c|c|c|c|}
\hline \multirow[b]{2}{*}{ Effect } & & \multicolumn{4}{|c|}{ White blood cell count $\left(10^{6} / \mathrm{L}\right)$ I,247 children, 4,981 measurement } \\
\hline & & Adj. Mean\# & Lower & Upper & $P$ \\
\hline \multirow[t]{5}{*}{ Quintiles of the area contamination: ${ }^{137}$ Caesium $\left(\mathrm{kBq} / \mathrm{m}^{2}\right)$} & $29-112$ & 6.87 & 6.58 & 7.16 & Ref. \\
\hline & $116-156$ & 6.88 & 6.60 & 7.18 & 0.94 \\
\hline & $165-253$ & 6.40 & 6.11 & 6.68 & 0.01 \\
\hline & $266-310$ & 5.95 & 5.55 & 6.35 & $<0.001$ \\
\hline & $350-879$ & 5.81 & 5.57 & 6.04 & $<0.001$ \\
\hline
\end{tabular}

$\Psi$ P-values are based on t-test compared with the reference (Ref.). \# Adjusted for age, sex, born after the accident, and year of measurement 
Table 7: Estimated effects of ${ }^{137}$ Caesium and year of measurements on erythrocyte count, hemoglobin, and platelet counts $\Psi$

\begin{tabular}{|c|c|c|c|c|c|c|c|c|c|c|c|c|c|}
\hline \multirow[b]{2}{*}{ Effect } & & \multicolumn{4}{|c|}{$\begin{array}{l}\text { Erythrocyte count }\left(10^{12} / \mathrm{L}\right) 698 \\
\text { children, } 2,404 \text { measurements }\end{array}$} & \multicolumn{4}{|c|}{$\begin{array}{l}\text { Hemoglobin }(\mathrm{g} / \mathrm{dL})^{\Phi} 698 \text { children, } \\
2,404 \text { measurements }\end{array}$} & \multicolumn{4}{|c|}{$\begin{array}{c}\text { Platelet count }\left(10^{9} / \mathrm{L}\right) 698 \text { children, } \\
2,403 \text { measurements }\end{array}$} \\
\hline & & Adj. Mean\# & $\begin{array}{r}5-c \\
\text { confi } \\
\text { inte }\end{array}$ & $\begin{array}{l}\text { ence } \\
\text { val }\end{array}$ & $P$ & Adj. Mean\# & $\begin{array}{r}5-c \\
\text { confi } \\
\text { inte }\end{array}$ & $\begin{array}{l}5 \% \\
\text { lence } \\
\text { rval }\end{array}$ & $P$ & Adj. Mean\# & $\begin{array}{l}5- \\
\text { conf } \\
\text { e int }\end{array}$ & $\begin{array}{l}5 \% \\
\text { denc } \\
\text { erval }\end{array}$ & $P$ \\
\hline \multirow{5}{*}{$\begin{array}{l}\text { Quintiles of the area } \\
\text { contamination: }{ }^{137} \mathrm{Cs} \\
\left(\mathrm{kBq} / \mathrm{m}^{2}\right)\end{array}$} & $29-112$ & 4.02 & 3.98- & 4.06 & Ref. & 12.2 & $12.1-$ & 12.3 & Ref. & 284 & 274 & 294 & Ref. \\
\hline & $116-156$ & 3.99 & 3.97- & 4.03 & 0.29 & 12.0 & 11.9 & 12.2 & 0.039 & 273 & 266 & 282 & 0.07 \\
\hline & $165-253$ & 4.00 & 3.93- & 3.93 & 0.42 & 12.1 & 12.0 & 12.2 & 0.34 & 281 & 273 & 290 & 0.52 \\
\hline & $266-310$ & 3.88 & 3.84- & 3.93 & $<0.001$ & 11.8 & 11.7 & 12.0 & 0.001 & 255 & 242 & 267 & $<0.001$ \\
\hline & $350-879$ & 3.96 & 3.93- & 3.99 & 0.009 & 12.0 & 11.0 & 12.1 & 0.033 & 264 & 256 & 271 & $<0.001$ \\
\hline
\end{tabular}

$\Phi$ I g/dL equals about $0.6206 \mathrm{mmol} / \mathrm{L}$.

$\Psi$ P-value are based on t-test compared with the reference (Ref.) in children born after the accident.

\# Adjusted for age, sex, and year of measurement

whereas the second to highest exposure group includes more children from small villages and rural areas with a larger chance of direct exposure externally and internally from food. Furthermore, compared to the virtue of individual measurements, using residential exposure data has the advantage that it provides the information needed to contribute to improved exposure regulations.

There are other sources of non-differential exposure misclassification, e.g., in landscapes with relatively low levels of radioactive contamination of the soil, the population may receive substantial radiation doses due to their consumption of contaminated food and vice versa. The results also show decreased erythrocyte counts and hemoglobin concentrations in 1996 in all exposure groups (Figures 2 and 3). It is possible that there was an instrument bias in 1996. Another explanation is that the winter in 1996 was colder. Thus, children may have suffered from a reduced supply of vitamins that are essential for the hematopoesis. Since the decline occurred in all exposure groups, this represents a non-differential misclassification. Non-differential misclassifications tend to produce results that underestimate effects and do not present a threat to validity of the findings.

Our data provide only a little information on individual characteristics such as age and gender. One may be inclined to consider that other confounding factors such as parental smoking or diet would increase the internal validity of this study. Against that, we need to understand the setting of this research. The Chernobyl accident affected all groups of the population, irrespective of whether the parent exposed their children to second hand smoke or whether their diet was healthy or not. Thus, smoking and other factors cannot act as confounders, since the accident resulted in a random distribution of radiation in relation to various other health related risk factors. Such a setting is referred to as quasi-experimental or as a randomized natural experiment $[28,29]$. Although this setting does not require the control of confounders, we cannot exclude other risk factors that may have moderated the adverse effects of radiation (effect modification or interaction). For instance, it is possible that poverty and unhealthy lifestyles have augmented adverse radiation effects. The sample of children was homogeneous. All families were poor villagers with a traditional diet based on local food and comparable domestic conditions. Given the setting of a randomized natural experiment, our results provide compelling evidence for the adverse effects of residential ${ }^{137} \mathrm{Cs}$ radiation on hematopoiesis.

Another limitation is that we have only computerized and statistically analyzed data for a limited time-period (1993-1998). However, this is a first step, and there is a clear need to include additional data before 1993 and after 1998. In addition, we had to start with a specific set of health outcomes and chose markers related to hematopoiesis. Other reports that document the various aspects of the Chernobyl accident will follow. These children seem to suffer from multiple diseases and co-morbidities with repeated manifestations, a condition for which the term 'frequently sick child' was defined by Stepanova and coworkers [30].

According to data from the Ukrainian Ministry of Social Protection (January 2005) and Ministry of Emergency, more than half a million children reside in areas with chronic exposure to low radiation due to soil contamination with ${ }^{137} \mathrm{Cs}$. We believe that it is extremely important to analyze not only cancer-related outcomes but also nonneoplastic effects [31], which are much more frequent than cancer. It is surprising that the UN Chernobyl Forum Report [2] did not consider multiple publications by Ukrainian, Russian, and Byelorussian researchers about 
the excess of non-cancer morbidity in children living in the territory contaminated by the Chernobyl accident [9,32-37]. Because the Chernobyl accident was like few others, there is a gap in knowledge regarding potential health sequelae. The atomic bombing of Japan near the end of World War II did release fission isotopes over a wide area, but the composition of this isotopic contamination was different [38]. The Chernobyl accident involved the release of isotopes built up in the fuel rods over time; these isotopes are far more persistent. As a potential consequence, the decreased blood counts show lasting effects. This was not observed after non-persistent radiation exposure [39]. However, similar effects were reported for the River Techa accident, which happened in 1957 [40]. The exposure was characterized by gamma and beta irradiation due to ${ }^{90}$ Strontium and ${ }^{137} \mathrm{Cs}$. As in children residing in Narodichesky region, adverse hematologic effects were detected. A normalization of the hematologic outcomes occurred only 13 years after the accident [40]. In investigating health sequelae in a cohort of children exposed to the Chernobyl accident, we expect to find associations that have not been reported before. This work is the first in a series using longitudinal epidemiology to uncover long-term effects of the Chernobyl accident on children, leading to a better understanding of how large and persistent the radiation exposure affects the general population.

\section{Conclusion}

More than 10 years after the Chernobyl accident, children in the Narodichesky region, Ukraine, approximately 80 $\mathrm{km}$ from Chernobyl, showed decreased counts for red and white blood cells and platelets, and a reduced concentration of hemoglobin associated with persistent residential ${ }^{137} \mathrm{Cs}$ exposure. There are compelling reasons to investigate more closely the relationship of radioactive exposure after the Chernobyl accident and health sequelae in children.

\section{Abbreviations}

Intraclass correlation coefficient (ICC), ethylene diamine tetraacetic acid (EDTA)

\section{Competing interests}

The authors declare that they have no competing interests.

\section{Authors' contributions}

Eugenia Stepanova and Vitaliy Vdovenko have contributed to developing the protocol of the medical exams and conducted the examinations and blood analyses. Wilfried Karmaus, Marina Naboka, Vitaliy Vdovenko, Tim Mousseau, John Vena, and Harris Pastides developed the analytical plan. Marina Naboka, Viacheslav M. Shestopalov, and Dwight Underhill provided access and supported the assessment of exposure data. Wilfried Karmaus and Erik
Svendsen analyzed the data. All the authors contributed to and approved the final manuscript.

\section{Additional material}

\section{Additional file 1}

Table with confidence limits. Estimated combined effects of 137Caesium irradiation and year of measurements on erythrocyte count, hemoglobin, and platelet counts and their confidence limits.

Click here for file

[http://www.biomedcentral.com/content/supplementary/1476069X-7-21-S1.doc]

\section{Acknowledgements}

Funding for the data entry was provided by the Samuel Freeman Charitable Foundation, the Walker Institute for International and Area Studies, and the National Science Foundation. We thank Susan Davis, Curtis Travis, Dmitry Afanasyev for their comments and and Wanzer Drane for the initial steps of the data collection.

\section{References}

I. Kinley D: Chernobyl's Legacy: Health, Environmental and Socio-Economic Impacts and Recommendations to the Governments of Belarus, the Russian Federation and Ukraine. Second revised version. 2006 [http://www.iaea.org/Publications/ Booklets/Chernobyl/chernobyl.pdf].

2. Bennett B, Repacholi M, Carr Z: Health Effect of the Chernobyl Accident and Special Health Care Programmes. Report of the UN Chernobyl Forum Expert Group "Health". 2006 [http://www.who.int/ionizing radiation/chernobyl/ WHO\%20Report\%20on\%20Chernobyl\%20Health\%20Effects\%20]uly \%2006.pdf].

3. Vasil'eva IM, Unzhakov SV, Meliksetova IA, Zasukhina GD, Semiachkina AN, Kazantseva LZ: [The adaptive response in the lymphocytes of children from an area with an elevated background of ionizing radiation]. Radiats Biol Radioecol 1995, 35:662-665.

4. Tedeschi B, Caporossi D, Vernole P, Padovani L, Mauro F: Do human lymphocytes exposed to the fallout of the Chernobyl accident exhibit an adaptive response? III. Challenge with bleomycin in lymphocytes from children hit by the initial acute dose of ionizing radiation. Mutat Res 1996, 354:77-80.

5. Fenech M, Perepetskaya G, Mikhalevich L: A more comprehensive application of the micronucleus technique for biomonitoring of genetic damage rates in human populations - experiences from the Chernobyl catastrophe. Environ Mol Mutagen 1997, 30:112-118.

6. Makedonov GP, Tskhovrebova LV, Unzhakov SV, Semiachkina AN, Vasil'eva IM, Zasukhina GD: [Radioadaptive response in lymphocytes of children living in territories polluted by radionuclides as a result of the accident at the Chernobyl power plant]. Radiats Biol Radioecol 1997, 37:640-644.

7. Padovani L, Stronati L, Mauro F, Testa A, Appolloni M, Anzidei P, Caporossi D, Tedeschi B, Vernole P: Cytogenetic effects in lymphocytes from children exposed to radiation fall-out after the Chernobyl accident. Mutat Res 1997, 395:249-254.

8. Mikhalevich LS, De Zwart FA, Perepetskaya GA, Chebotareva NV, Mikhalevich EA, Tates AD: Radiation effects in lymphocytes of children living in a Chernobyl contaminated region of Belarus. Int J Radiat Biol 2000, 76:1377-1385.

9. Lenskaia RV, Buiankin VM, Zakharova GA, Ikonnikova OA, Koliaskina MG, Popova OA, Rumiantsev AG, Seleznev VA, Sterligova IA, Chernov VM: [Cytochemical lymphocytic markers as criteria suitable for mass and selective hematologic screening of children living in areas contaminated by radionuclides]. Gematol Transfuziol 1993, 38:34-36. 
10. Vykhovanets EV, Chernyshov VP, Slukvin II, Antipkin YG, Vasyuk A, Colos V: Analysis of blood lymphocyte subsets in children living around Chernobyl exposed long-term to low doses of cesium- 137 and various doses of iodine-13 I. Radiat Res 2000, 153:760-772.

II. Chernyshov VP, Vykhovanets EV, Slukvin II, Antipkin YG, Vasyuk AN, Strauss KW: Analysis of blood lymphocyte subsets in children living on territory that received high amounts of fallout from Chernobyl accident. Clin Immunol Immunopathol I997, 84: I22-I 28.

12. Livingston GK, Jensen RH, Silberstein EB, Hinnefeld JD, Pratt G, Bigbee WL, Langlois RG, Grant SG, Shukla R: Radiobiological evaluation of immigrants from the vicinity of Chernobyl. Int J Radiat Biol 1997, 72:703-7/3.

13. Vartanian LS, Gurevich S, Kozachenko AI, Nagler LG, Burlakova EB: [Age-related peculiarities of effect of low dose ionizing radiation on blood antioxidant enzyme system status in Chernobyl's accident liquidation participant]. Adv Gerontol 2004, I 4:48-54.

14. Stepanova El, Davidenko OA, Vdovenko V: [Peculiarities of superficial architectonics of peripheral blood erythrocytes in children irradiated in utero and living in the radioactivecontaminated areas]. Tsitol Genet 2006, 40:40-43.

15. Spirichev VB, Donchenko GV, Blazheevich NV, Parkhomenko lu M, Aleinik SI, Golubkina NA, Vrzhesinskaia OA, Isaeva VA, Kodentsova VM, Pereverzeva OG, Sokol'nikov AE, lakushina LM: [To the 20th anniversary of the Chornobyl accident study of vitamin status and provision with micro- and macroelements of limited groups of people at different time periods since the accident at Chornobyl nuclear power plant]. Ukr Biokhim Zh 2006 , 78:5-26.

16. Bebeshko VG, Bruslova EM, Tsvetkova NM: Hemopoietic system state in children under the chronic radiation impact within low dose range. In Clinical effects of the Chernobyl disaster Edited by: Bebesko VG, Kovalenko AN. Kiev: Academy of Medical Science; 1999:21.

17. Yamashita S, Shibata $Y,(E d s)$ : Chernobyl: A Decade. Proceedings of the Fifth Chernobyl Sasakava Medical Cooperation Symposium, 14-15 October 1996 Kiev, Ukraine: Elsevier; 1996.

18. Avramenko A: Health conditions of children in the Kiev region 10 years after the Chernobyl nuclear power plant accident: based on the results of health examination made by the Chernoby Sasakawa Diagnostic Center (Kiev Regional Hospital No. 2). In Chernobyl: A Decade Proceedings of the Fifth Chernobyl Sasakava Medical Cooperation Symposium, Kiev, Ukraine, 14-15 October 1996 Edited by: Yamashita S, Shibata Y. Amsterdam, Lausanne, New York: Elsevier; 1997:3-10.

19. Karevskaya IV, Fokina MM, Kozyreva EA, Drozdovich VS, Averichev AA, Demidenko AN, Derzhtskaya EV, Cot VA, Moiseyenko NV, Koulikova NV, Kroupnik TA, Sribnaya VD, Tkachuk LP, Avramenko Al, Petrova AA, Voropai LV, Masyakin VB, Daniliuk LV, Daniliuk VV: Hematological finding of the Chernoby Sasakawa Health and Medical Cooperation Project. In Chernobyl: A Decade Proceedings of the Fifth Chernobyl Sasakava Medical Cooperation Symposium, Kiev, Ukraine, 14-15 October 1996 Edited by: Yamashita S, Shibata Y. Amsterdam, Lausanne, New York: Elsevier; 1997:45-57.

20. All-Ukrainian population census '200I [http://www.ukrcen sus.gov.ua./eng/results/general/urban-rural/Zhytomyr]

21. Ministry of Health of the Ukraine: Certification doses for the settlements of Ukraine located in contaminated territories after the Chernobyl accident Reports No I to 7 and 9 and 10. Kiev 2005.

22. Ministry of Emergency Situation of Ukraine: Atlas of radioactivity contamination of the Ukraine. Kiev 2002.

23. Sharifov VF, Koulikova NV, Voropai LV, Kroupnik TA, Masyakin VB, Cot VA, Kovalev Al, Aksenov AS, Averichev AA, Moiseyenka MY, Avramenko Al, Goncharenko OE, Daniliuk VV: Finding of the Chernoby Sasakawa Health and Medical Cooperation Project: 137 Cs concentrations among children around Chernobyl. In Chernobyl: A Decade Proceedings of the Fifth Chernobyl Sasakava Medical Cooperation Symposium, Kiev, Ukraine, 14-15 October 1996 Edited by: Yamashita S, Shibata Y. Amsterdam, Lausanne, New York: Elsevier; 1 997:39-44.

24. Nicholson JF, Pesce M: Reference Ranges for Laboratory Tests and Procedures. In Nelson textbook of pediatrics I6th edition. Edited by: Behrman RE, Kliegman RM, Jenson HB. Philadelphia: W.B. Saunders Company; 2000:2181-2229.
25. Armstrong B, White E, Saracci R: Principles of Exposure Measurement in Epidemiology Oxford, New York, Tokyo: Oxford University Press; 1992.

26. Verbeke G, Molenberghs G: Linear Mixed Models for Longitudinal Dato New York: Springer-Verlag; 2000.

27. International Programme on the Health Effects of the Chernoby Accident: Health Consequences of the Chernobyl Accident. Results of the IPHECA Pilot Projects and Related National Programmes. Scientific Report. Geneva 1996.

28. Goldberg J, Richards MS, Anderson RJ, Rodin MB: Alcohol consumption in men exposed to the military draft lottery: a natural experiment. I Subst Abuse 1991, 3:307-313

29. Carrozzi L, Giuliano G, Viegi G, Paoletti P, Di Pede F, Mammini U, Carmignani G, Saracci R, Giuntini C, Lebowitz MD: The Po River Delta epidemiological study of obstructive lung disease: sampling methods, environmental and population characteristics. Eur J Epidemiol 1990, 6:19|-200.

30. Stepanova El, Kolpakov I, Vdovenko VY: State of the functional system in children exposed to radiation effect as a result of the Chernobyl catastrophe Kiev: Chernobyl Inform Press; 2003.

3I. Busby C, Fucic A: lonizing radiation and children's health: conclusions. Acta Paediatr Suppl 2006, 95:8I-85.

32. Astakhova LN, Demidchuk EP, Davydova EV, Arinchin AN, Gres NA Zelenko SM, Drozd VM, Poliakova TI, Dardynskaia IV, Bazyl'chik SV: [Health status of Byelorussian children and adolescents exposed to radiation as consequence of the Chernobyl AES accident]. Vestn Akad Med Nauk SSSR I99I, I I:25-27.

33. Stepanova El, Kondrashova VG, Davidenko OA, Kniazeva OB, Galichanskaia $\mathrm{T}$ : [The hematological effects of the Chernobyl accident in children]. Gematol Transfuziol 1992, 37:3I-33.

34. Stepanova El, Chaialo PP, Kolpakov IE, Kondrashova VG, Kurilo LV Galichanskaia T, Fediakova OB, Ivaniuk AG: [Effects of the consequences of the Chernobyl accident on the child's body]. Pediatria |99|, |2:8-13.

35. Lukyanova EM: Klinical and practical aspects of pediatric health nine years after the Chernobyl disaster. JAMS of Ukraine 1996, I:21-23.

36. Bobylova OA: Health state estimate in children depending on the occured radio-ecological situation after the ChNPP accident. Ukraine Radiology Journal I996, I:21-23.

37. Nyagu Al, Loganovsky KN, Nechaev SY, Pott-Born R, Repin VS, Antipchuk EY, Bomko MA, Yurryev KL, Petrova IV: Effects of prenatal brain irradiation as a result of Chernobyl accident. Int J Radial Med 2004, 6: I-4.

38. Baverstock K, Williams D: The chernobyl accident 20 years on: an assessment of the health consequences and the international response. Environ Health Perspect 2006, I 14:1312-1317.

39. Scherthan $\mathrm{H}$, Abend M, Muller K, Beinke $\mathrm{C}$, Braselmann $\mathrm{H}$, Zitzelsberger H, Kohn FM, Pillekamp H, Schiener R, Das O, Peter RU, Herzog G, Tzschach A, Dorr HD, Fliedner TM, Meineke V: Radiation-induced late effects in two affected individuals of the Lilo radiation accident. Radiat Res 2007, 167:615-623.

40. Akleyev AV, Kossenko MM, Silkina LA, Degteva MO, Yachmenyov VA, Awa A, Akiyama M, Veremeyeva GA, Vozilova AV, Kyozumi S: Health effects of radiation incidents in the southern Urals. Stem Cells 1995, I3(Suppl I):58-68.

Publish with Bio Med Central and every scientist can read your work free of charge

"BioMed Central will be the most significant development for disseminating the results of biomedical research in our lifetime. "

Sir Paul Nurse, Cancer Research UK

Your research papers will be:

- available free of charge to the entire biomedical community

- peer reviewed and published immediately upon acceptance

- cited in PubMed and archived on PubMed Central

- yours - you keep the copyright 